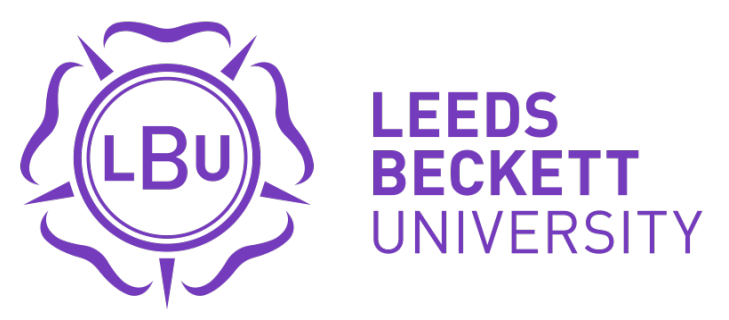

Citation:

Blackledge, PR (2014) Alasdair Maclntyre as a Marxist and as a critic of Marxism. American Catholic Philosophical Quarterly, 88 (4). 705 - $724 . \quad$ ISSN 1051-3558 DOI: https://doi.org/10.5840/acpq201491127

Link to Leeds Beckett Repository record:

https://eprints.leedsbeckett.ac.uk/id/eprint/555/

Document Version:

Article (Updated Version)

The aim of the Leeds Beckett Repository is to provide open access to our research, as required by funder policies and permitted by publishers and copyright law.

The Leeds Beckett repository holds a wide range of publications, each of which has been checked for copyright and the relevant embargo period has been applied by the Research Services team.

We operate on a standard take-down policy. If you are the author or publisher of an output and you would like it removed from the repository, please contact us and we will investigate on a case-by-case basis.

Each thesis in the repository has been cleared where necessary by the author for third party copyright. If you would like a thesis to be removed from the repository or believe there is an issue with copyright, please contact us on openaccess@leedsbeckett.ac.uk and we will investigate on a case-by-case basis. 


\section{Alasdair MacIntyre as a Marxist and as a critic of Marxism}

\section{Paul Blackledge ${ }^{1}$}

\section{Introduction}

In his 1995 introduction to Marxism and Christianity, Alasdair MacIntyre claimed that Marxism 'is the only secular post-enlightenment doctrine to have' a metaphysical and moral scope comparable to that of Christianity. ${ }^{2}$ This was not meant as a mere academic point, for Marxism: An Interpretation (the title of the first, 1953, edition of Marxism and Christianity) was written as a contribution to what he hoped would be a renewal of Christianity. MacIntyre was drawn towards Marxism because, as he saw it, Marx's political theory converged with his vision of critical Christian ethics: 'Marxism is of first-class theological significance as a secularism formed by the gospel which is committed to the problem of power and justice and therefore to themes of redemption and renewal which its history cannot but illuminate'. ${ }^{3}$ Moreover, he perceived a parallel between the situation faced by Marx in the early 1840s and that encountered by contemporary [1950s] Christians. Whereas Marx 'was faced with a stark antithesis' between both Hegel's and Feuerbach's visions of human freedom, and the reality of the world of work and suffering, contemporary Christianity accepted a split between the sacred and the secular such that it had lost any critical perspective on the world. Indeed, because modern Christianity had reduced faith to a matter of personal taste, it no longer concretely criticised social injustice and thus did not interfere with daily secular existence. MacIntyre believed that Christians would do well to learn from Marx's turn to politics in his attempt to overcome the gap between reality and the vision of freedom in Hegel's system. ${ }^{4}$

It is important that this argument informs a reading of MacIntye's claim that 'my critique of liberalism is one of the few things that has gone unchanged in my overall view throughout my whole life. Ever since I understood liberalism, I have wanted nothing to do with it - and that was when I was seventeen years old'.5 MacIntyre critique of liberalism was profoundly influenced by Marx, and his intellectual evolution over the past six decades has been marked by this influence alongside his Christianity. Indeed, it is very interesting that he eventually came to reject Marxism not so much for its revolutionary substance but rather for its failure fully to disarticulate itself from inherited aspects of liberal theory, particularly liberal moral theory. ${ }^{6}$

MacIntyre's criticisms of liberal moral theory are well known and need only be briefly restated. In After Virtue he famously argued that in the modern world moral

\footnotetext{
${ }^{1}$ This essay extends arguments first outlined in several earlier essays including 'Freedom, Desire and Revolution: Alasdair MacIntyre’s Early Marxist Ethics', History of Political Thought Vol. XXVI, No. 4, 2005: 696-720; 'Morality and Revolution: Ethical Debates in the British New Left', Critique Vol. 35, No. 2, 2007 : 203-220; ‘Alasdair MacIntyre’s Contribution to Marxism: A Road not Taken', Analyse and Kritik, Vol. 30, No. 1, 2008: 215-227; and in an essay co-written with Neil Davidson, 'Introduction: The Unknown Alasdair MacIntyre’, in Paul Blackledge \& Neil Davidson eds. 2008, Alasdair MacIntyre’s Engagement with Marxism: Essays and Articles 1953-1974 Leiden: Brill: xiii-l.

2 Alasdair MacIntyre 1995, 'Introduction, 1953, 1968, 1995: Three Perspectives' in Marxism and Christianity (London: Duckworth), p. vi, Republished as 'Three Perspectives on Marxism: 1953, 1968, 1995' in Alasdair MacIntyre 2006, Ethics and Politics (Cambridge: Cambridge University Press), p. 146

${ }^{3}$ Alasdair MacIntyre 1953, Marxism: An Interpretation (London: SCM), p. 18. For the relationship between MacIntyre's youthful Christianity and his Marxism see Peter McMylor 1994, Alasdair MacItnyre: Critic of Modernity (London: Routledge) and his 'Marxism and Christianity: Dependencies and Differences in Alasdair MacIntyre’s Critical Social Thought’, Theoria, Vol. 55, No. 116, August 2008: 45-66

${ }^{4}$ Alasdair MacIntyre, Marxism: An Interpretation, pp. 45; 10

${ }^{5}$ Alasdair MacIntyre 1994, 'Interview with Professor Alasdair MacIntyre’, Kinesis, 20, 34-47, p. 43

${ }^{6}$ Alasdair MacIntyre 1985, After Virtue: A Study in Moral Theory (London: Duckworth), p. x.
} 
arguments could be reduced to 'masks for expressions of personal preference' whose premises often proved to be incommensurable. Indeed, he suggested that Marx was 'right when he argued against the English trade unionists of the 1860s that appeals to justice were pointless, since there are rival conceptions of justice formed by and informing the life of rival groups'. Furthermore, though he disagreed with Marx's suggestion that contestations over the nature of justice were secondary social phenomena, he believed that Marx was 'fundamentally right in seeing conflict and not consensus at the heart of modern social structure': 'modern politics is civil war carried out by other means'.

Nonetheless, though MacIntyre expected Marxists would be sympathetic to a great deal of the critique of liberal individualist (bourgeois) morality outlined in After Virtue, he believed that they would reject his 'realistic' political alternative to the status quo. This realism grew in part out of a critique of Marx's alternative to capitalism. Against Marxism, MacIntyre argued, first, that in the century since Marx's death, insofar as Marxists had taken 'explicit moral stances' they tended to fall back on either one form or another of 'Kantianism or utilitarianism'. Second, Marx failed to conceptualise the means through which his vision of 'a community of free individuals' was to be constructed. Third, Marxists in power had tended to become Weberians. Fourth, Marx's political optimism was undermined by capitalism's tendency to morally impoverish the human resources necessary to renew society. Additionally, he insisted that anyone who took Trotsky's mature analysis of the Soviet Union seriously ${ }^{8}$ would be drawn to embrace a form of political pessimism that was incompatible with Marxism. Finally, he argued that in conditions of moral impoverishment, Marxists were wont to construct their own 'versions of the Ubermensch'. For instance, 'Lukács's ideal proletarian' or 'Leninism's ideal revolutionary'.

More recently MacIntyre has added the claim that while workers may have embodied in their practice a revolutionary ethics of emancipation at certain moments in history, the process of proletarianisation, by contrast with Marx's expectations to the contrary, simultaneously made resistance a necessary part of the lives of the working class while robbing this resistance of its emancipatory potential. Proletarianisation 'tends to deprive workers of those forms of practice through which they can discover conceptions of a good and of virtues adequate to the moral needs of resistance'. ${ }^{10}$ Consequently, whereas MacIntyre had, in the late 1950s and early 1960s, argued that working class struggles could provide the basis for the creation of a truly human community, in the 1980s he saw no alternative to liberal individualism except as a form of virtue ethics rooted in the practices of small communities.

There is much to commend in MacIntyre's critique of Marxism, particularly his claim that Marxists have tended to oscillate between Kantian and utilitarian justifications for their politics. Conversely, he has outlined a powerful and appealing critique of liberal ethics

\footnotetext{
${ }^{7}$ Alasdair MacIntyre, After Virtue, pp. 19; 250; 252-3; 113.

${ }^{8}$ One problem with this argument is that Trotsky's understanding of the class nature of the Soviet Union was, as MacIntyre had previously argued, in a process of change at the time of his death. See Alasdair MacIntyre [1963] 2008, 'Trotsky in Exile' in Paul Blackledge \& Neil Davidson eds., Alasdair MacIntyre's Engagement with Marxism: Essays and Articles 1953-1974, Leiden: Brill. For a sense of Trotsky's evolving position see his 'The USSR in War' in Leon Trotsky 1990, In Defense of Marxism (New York: Pathfinder), and for a discussion of the contradictions between Trotsky's analysis of the Soviet Union and his broader interpretation of Marxism see my 'Results and Prospects: Trotsky and his Critics', in Bill Dunn \& Hugo Radice eds. 2006, Permanent Revolution: Results and Prospects 100 Years On (London: Pluto Press): 48-60

${ }^{9}$ Alasdair MacIntyre, After Virtue, pp. 261-2; See also Alasdair MacIntyre 1967, A Short History of Ethics (London: Routledge), p. 214

${ }^{10}$ Alasdair MacIntyre 1998, 'The Theses on Feuerbach: A Road Not Taken' in Kelvin Knight ed. The MacIntyre Reader (Cambridge: Polity), p. 232.
} 
that draws deeply, as Fredric Jameson points out, on the rich legacy of the Marxist tradition. ${ }^{11}$ This Marxist influence on his work marks a continuity with his youthful writings when he suggested a Marxist route out of the dead ends of Kantian and utilitarian ethics while, contra more recent analytical contributions to debates about Marxism and morality, remaining true to Marx's revolutionary political project. ${ }^{12}$ The reasons for MacIntyre's rejection of this project in the 1960s, included, as I have argued elsewhere, his dismissal both of Marx's theory of economic crisis and any essentialist theories of human nature. ${ }^{13}$ Interestingly, he has recently signalled a change of heart on both these issues. Thus, whereas the arguments of A Short History of Ethics and After Virtue similarly involved refusals of the concept of human nature, Dependent Rational Animals includes the argument that the theses of these books were weakened by their shared supposition of the possibility of 'an ethics independent of biology'. ${ }^{14}$ Moreover, his introduction to the 1995 edition of Marxism and Christianity suggests that he had previously been too harsh on Marx's labour theory of value, and by implication his theory of crisis. ${ }^{15}$ In thus reappraising his relationship to Marx's economic theory and more general theories of human nature, MacIntyre has significantly reduced the theoretical space between his mature thought and his early Marxism.

This shift is evident in the 2004 preface to his 1958 study of Freud: The Unconscious. In this essay he reasserts the necessity of linking psychoanalysis and politics through the concept of desire in a way that is reminiscent of his early Marxism, but which stands in sharp contrast to the general trajectory of his thought from the 1960 s to the $1980 \mathrm{~s}^{16}$ While a large gap remains between MacIntyre's contemporary moral and political thought and Marxism, his changed perspective at least opens up the possibility of a renewed dialogue between the two. ${ }^{17}$ It is with a view to facilitating such a dialogue that this essay traces the contours of MacIntyre's relationship with Marxism in the 1960s. In particular, I want to interrogate MacIntyre's claim that Marxism's moral flaws stem from its liberal inheritance through the lens of his discussion of the problem of organised socialist agency within the class struggle. Indeed, I argue that this problem, the problem of socialist leadership, sits at the core of MacIntyre's critique of Marxism.

\section{MacIntyre’s Early Marxism}

There is a contradiction at the heart of Marxism. On the one hand, Marx holds to an ultrademocratic conception of socialism as a process of proletarian self-emancipation, while, on the other hand, he insists that the dominant ideas in society are at any given time the ideas of the ruling class. ${ }^{18}$ Simply put, the latter claim seems to negate the possibility of the former. This contradiction has been expressed by many Marxist intellectuals through a fundamental misconception of the role of socialist militants within the workers' movement. Whereas some

\footnotetext{
${ }^{11}$ Fredric Jameson 1988, 'Morality versus Ethical Substance’ in Fredric Jameson The Ideologies of Theory: Essays 1971-1986 Vol. 1 (Minneapolis: University of Minnesota Press), p. 181.

12 See Paul Blackledge 2012, Marxism and Ethics (New York: SUNY Press), pp. 150-157; 179-189

${ }^{13}$ Paul Blackledge 2005, 'Freedom, Desire and Revolution: Alasdair MacIntyre's Marxist Ethics' History of Political Thought Vol. XXVI, No. 4.

${ }^{14}$ Alasdair MacIntyre 1999, Dependent Rational Animals (London: Duckworth), p. x.

${ }^{15}$ Alasdair MacIntyre 1995, 'Introduction' to second edition of Marxism and Christianity, p. xx; 2006, 'Three Perspectives on Marxism: 1953, 1968, 1995’, p. 152

${ }^{16}$ Alasdair MacIntyre 2004, The Unconscious: A Conceptual Analysis (London: Routledge), pp. $27 ; 114$.

${ }^{17}$ See, for instance, MacIntyre's reply to his critics, including myself, in 'Where we were, Where we are, Where we need to be’ in Paul Blackledge \& Kelvin Knight eds. 2011, Virtue and Politics (University of Notre Dame Press)

${ }^{18}$ Tony Cliff 2001, 'Revolution and Counter-Revolution: Lessons for Indonesia’ in Tony Cliff International Struggles and the Marxist Tradition, London: Bookmarks, 311-326, p. 317
} 
have downplayed this role through a fatalistic assumption about the victory of socialism being guaranteed by the laws of history, others have effectively embraced a voluntaristic view of history in which militants play the role of anti-Nietzschean supermen (who are unfortunately characterised by all the negatives of the original but without their sense of selfawareness!).

That this contradiction has roots in reality does not detract from the fact that it presents a very real problem for Marxists. To the extent that Marxists have engaged with this issue they have tended to address it as a political rather than a moral concern - usually through the medium of a contrast between Lenin's vanguardist model of socialist leadership and Rosa Luxemburg's defence of the spontaneous creativity of working-class struggle.

Though this is a largely caricatured debate, ${ }^{19}$ its polarities express important aspects of social reality. Who would want, for instance, to reject the ideas either of leadership or of spontaneity when assessing the recent revolutionary movement in Egypt? In the third of his theses on Feuerbach Marx addressed this contradiction through the concept of revolutionary practice: 'the coincidence of the changing of circumstances and of human activity or selfchanging can be conceived and rationally understood only as revolutionary practice'. Though this claim can clearly be interpreted as leaning towards Luxemburg's interpretation of Marxism, it is not difficult to find quotations from Marx that equally prefigure Lenin's writings: for instance in the 1850 March Address he wrote 'the workers' party, therefore, must act in the most organised, most unanimous and most independent fashion possible'. ${ }^{20}$

In relation to moral theory, while fatalism, like pre-Marxist materialism, leaves little space for free will and morality, voluntarism points in the opposite direction towards an abstract conception of agency that, like Kantian morality, doesn't know real sensuous human activity as such. ${ }^{21}$ It is unsurprising that revolutionary socialists who have embraced a variant of political voluntarism, including perhaps most famously Karl Liebknecht, there has been a tendency to reduce socialist morality to a form of Kantianism. And though Liebknecht won MacIntyre's admiration - 'one Liebknecht [is worth] a hundred Webers' ${ }^{22}$ - the path to Kant was clearly not one he was likely to follow. Conversely, Karl Kautksy, who tends to play the role of Liebknecht's fatalistic other within the annals of the international socialist movement, has rightly been dismissed by MacIntyre for the opposite error of deifying history as the arbiter of moral judgement. ${ }^{23}$

At one level these are unoriginal criticisms of voluntaristic and fatalisitic variants of Marxism. Neither does MacIntyre's originally lie in the generalisation of these criticisms to Marxism as a whole. Indeed, his 1973 critique of Lenin for embracing an 'ideology of expertise' in which the revolutionary 'cannot avoid in himself the very elitism which he attacks in others ${ }^{24}$ is uninteresting insofar as it rehearses what Lars Lih calls the 'textbook

\footnotetext{
${ }^{19}$ Paul Blackledge 2006, 'What was Done’, International Socialism 2/111, p. 116

${ }^{20}$ This is the third of Marx’s famous theses on Feuerbach. Karl Marx 1975, 'Theses on Feuerbach.' In Karl Marx, Early Writings, (London: Penguin) 421-423; Karl Marx and Frederick Engels, 1978, 'Address of the Central authority to the League: March 1850’; Marx and Engels Collected Works Vol. 10: 277-287, p. 278.

${ }^{21}$ Thus in the third thesis on Feuerbach Marx wrote that ' $[t]$ he chief defect of all hitherto existing materialism that of Feuerbach included - is that the thing, reality, sensuousness, is conceived only in the form of the object or of contemplation, but not as sensuous human activity, practice, not subjectively. Hence, in contradistinction to materialism, the active side was developed abstractly by idealism - which, of course, does not know real, sensuous activity as such.’ Karl Marx 1975, ‘Theses on Feuerbach.’ In Karl Marx, Early Writings, (London: Penguin) 421-423

22 Alasdair MacIntyre [1976] 'Causality and History’ in Juha Manninen and Raimo Tuomela, eds. Essays on Explanation and Understanding (D. Reidel) quoted in Kelvin Knight 2007, Aristotelian Philosophy, Cambridge: Polity, p. 127

${ }^{23}$ Alasdair MacIntyre 1968, Marxism and Christianity (London: Duckworth), p. 101

${ }^{24}$ Alasdair MacIntyre 1973, 'Ideology, Social Science and Revolution’, Comparative Politics, v. 5, n. 3, July, pp. 340-342.
} 
interpretation' of Leninism. ${ }^{25}$ Rather, MacIntyre’s importance as a critic of Marxism stems from his awareness of the ethical implications of this criticism; in particular his claim that Lenin's failings reflect the sedimentation within Marxism of aspects of the liberal inheritance that Marxists have never adequately addressed.

What is particularly interesting about MacIntyre's critique of Marxism is the route through heterodox-Trotskyism by which he came to these conclusions. Elsewhere I have traced the process whereby he intervened within an ethical debate within the British New Left after 1956 to articulate a distinct and novel Marxist ethics of liberation in opposition to both Kantian and consequentialist alternatives. Briefly summarised, this debate had Edward Thompson and Harry Hanson play the roles of consequentialist and Kantian respectively, while MacIntyre intervened from a position strongly influenced by Marx's dialectical sublation of materialism and idealism. Thompson, in his essay 'Socialist Humanism' (1957), criticised the Stalinists for the inhumanity of their system, but tacitly accepted their consequentialist frame of reference, when he commented that, although they had employed bad means, the Russians had gone some way towards realising, at least aspects of, socialism. Conversely, Hanson denounced the Stalinist experiment tout court as an assault on basic human rights. ${ }^{26}$ If Hanson criticised Thompson's moral consequentialism without providing a viable alternative to it, Charles Taylor argued that Thompson's attempt to retrieve a vibrant Marx from the carcass of Stalinism elided over deep problems within Marxism itself. For Marx's understandable impatience with abstract moral criticisms of capitalism, and his counter-position of proletarian virtue to bourgeois morality could easily slip into a justification for the type of revolutionary elitism that had morphed into Stalinism. The party, according to Taylor, could imagine itself as the embodiment of proletarian virtue against the real inadequacies of the proletariat. ${ }^{27}$

In his contribution to this debate, MacIntyre sought to defend the essence of Thompson's socialist humanism so that it was no longer susceptible to the types of critique mounted by Hanson and Taylor. The resulting essay, 'Notes from the Moral Wilderness', reads in many ways as a precursor to the thesis of After Virtue, but without the concluding dismissal of Marxism. In opposition both to Stalin's teleology of historical progress and to Kant's ahistorical categorical imperative, MacIntyre suggested that we should look for a 'theory which treats what emerges in history as providing us with a basis for our standards, without making the historical process morally sovereign or its progress automatic' ${ }^{28}$ He went on to argue that if Marxists were to make human actions intelligible then they should, contra Kant, follow Aristotle in linking ethics to human desires. ${ }^{29}$

Nevertheless, MacIntyre followed Marx in accepting that human desires had been remoulded by capitalism such that it was important to ask, first, if this remoulding was absolute, and, second, if it was not absolute was it possible that it might be transcended? To understand these issues historically it is necessary to ask if a form a human nature could emerge in the modern world such that the needs and desires of individuals are not felt to be in simple atomised opposition one to the other? Marx, according to MacIntyre, comprehended both the deep historical and sociological content to this question when he suggested that 'the emergence of human nature is something to be comprehended only in terms of the history of

\footnotetext{
${ }^{25}$ Lars Lih 2006, Lenin Rediscovered (Leiden: Brill)

${ }^{26}$ Edward Thompson 1957, 'Socialist Humanism' The New Reasoner 1, Summer; Harry Hanson 1957, 'An Open Letter to Edward Thompson' The New Reasoner 2, Autumn.

${ }^{27}$ Taylor, Charles 1957, 'Marxism and Humanism’ The New Reasoner 2, Autumn. Cf. Taylor, Charles 1957, 'Socialism and Intellectuals - Three', Universities and Left Review 2, Summer.

${ }^{28}$ Alasdair MacIntyre [1958-9] 2008, 'Notes from the Moral Wilderness' in Paul Blackledge \& Neil Davidson eds., Alasdair MacIntyre’s Engagement with Marxism: Essays and Articles 1953-1974, Leiden: Brill, p. 57.

${ }^{29}$ Alasdair MacIntyre, 'Notes from the Moral Wilderness', pp. 58-60.
} 
class-struggle. Each age reveals a development of human potentiality which is specific to that form of social life and which is specifically limited by the class-structure of that society'. In particular, under advanced capitalism, 'the growth of production makes it possible [for man] to re-appropriate his own nature'. This is true in two ways: first, the increasing productivity of labour produces the potential for us all to lead much richer lives, both morally and materially; and second, capitalism also creates an agency - the proletariat - which, through its struggles for freedom, embodies a new collectivist spirit, out of which individuals come to understand both that their needs and desires can best be satisfied through collective channels, and that they do in fact need and desire solidarity. ${ }^{30}$ According to MacIntyre in 1958-9, the proletariat, in its struggles against capital, was beginning to create the conditions for the solution of the contemporary problems of morality; it embodies the practice which could overcome the 'rift between our conception of morality and our conception of desire' ${ }^{31}$

\section{On Self-Emancipation and Socialist Leadership}

Though MacIntyre believed that the link between socialism and proletarian practice was inscribed within capitalist relations of production, at the turn of the 1960s he did not accept that the socialist potential of the struggles of the working class could be realised independently of some form of political organisation. In an argument strongly influenced by perspectives developed in the French Marxist journal Socialisme ou Barbarie, he claimed that socialist ideas where not to come, pace Kautsky and Lenin, from without the working class, but would be rooted in worker's consciousness of the spontaneous struggles against capital at the 'point of production'. He argued that a revolutionary socialist party should therefore orientate towards these struggles because it was at this level that the dominance of bourgeois ideas began to be challenged and thus where people in 'our society ... begin to act and think for themselves'. 32

Edited by Cornelius Castoriadis and Claude Lefort, Socialisme ou Barbarie was one of a number of groupings to emerge out of the post-war crisis of Trotskyism. These factions were united in agreeing, negatively, that Trotsky had been wrong to classify the Soviet social formation as a degenerate workers state, and, positively, that Stalin's Russia was a form of state capitalism. Alongside Castoriadis' French grouping, this international milieu included the American Johnson-Forrest Tendency led by Raya Dunayevskaya and CLR James and the British Socialist Review/International Socialism group led by Tony Cliff and Mike Kidron. ${ }^{33}$ Interestingly, by placing Marx's concept of proletarian self-emancipation at the centre of their criticism of orthodox Trotskyism, all three of these groups were drawn towards questioning the relationship of Leninism to Marxism.

MacIntyre's attempt to come to terms with the dialectic of spontaneity and leadership within the socialist movement was profoundly influenced by these debates. In 'Breaking the Chains of Reason', he insisted that freedom cannot be won by telling the masses to do what the elite desires it do, but only by helping 'them move where they desire. The goal is not happiness, or satisfaction, but freedom. And freedom has to be both means

\footnotetext{
${ }^{30}$ Alasdair MacIntyre, 'Notes from the Moral Wilderness', p. 64.

${ }^{31}$ Alasdair MacIntyre, 'Notes from the Moral Wilderness', p. 63.

32 Alasdair MacIntyre 2008, 'The 'New Left'” in Paul Blackledge \& Neil Davidson eds., Alasdair MacIntyre's Engagement with Marxism: Essays and Articles 1953-1974, Leiden: Brill, p. 89; cf Cornelius Castoriadis 'The Proletariat and Organisation’ Socialisme Ou Barbarie 1959 reprinted in Cornelius Castoriadis 1988, Political and Social Writings Vol. II, (Minneapolis: University of Minnesota Press).

${ }^{33}$ According to Marcel van der Linden all three of these groups broke with orthodox Trotskyism between 1948 and 1951, and kept in contact with each other over the next decade. Cf Marcel van der Linden 'Socialisme ou Barbarie: A French Revolutionary Group (1949-65)’ Left History 5.11997.
} 
and ends. The mechanical separation of means and ends is suitable enough for human manipulation, not human liberation'. ${ }^{34}$ Moreover, for MacIntyre, emancipatory politics emerge spontaneously through the struggles of the working class against capitalism. ${ }^{35}$ Because freedom is both the means and end of socialist activity, such activity, contra the Kantians, required a strong anchorage in contemporary history, while, contra the consequentialists, it was not a reified end that could be inaugurated by any one of a variety of means. MacIntyre concluded, 'the philosophers have continued to interpret the world differently; the point remains, to change it'.

MacInyre's most important contribution to the debate on socialist strategy, 'Freedom and Revolution', articulated a broader socialist politics rooted in the experience of workers at the point of production. Published in Labour Review early in 1960, this essay challenged the negative liberal understanding of freedom that was common within New Left criticisms of Leninism through the medium of the Hegelian argument that human freedom can only be realised through some form of social organisation. He suggested that because capitalism constrains human freedom, the struggle for freedom must involve a struggle against capitalism. Moreover, this struggle demanded a 'vanguard party' because the working class, on whose conscious agency socialism depended, could not achieve socialist consciousness 'spontaneously'. The role of the vanguard party was, therefore, not to build freedom, but to move 'the working class to build it'.

To the extent that MacIntyre complemented this insight with a concrete discussion of the mechanisms through which the party might interact with the working class in this process, he merely noted that it should act as an organisation of 'continuous education' through which it would 'enable its members to withstand all the pressures of other classes and to act effectively against the ruling class'. Moreover, he noted that this function required some form of discipline through which the party might guard itself against 'alien class pressures'. Thus, against the tendency within the New Left to equate their break with Stalinism with a fundamental critique of Leninism, MacIntyre defended the applicability of Leninism to an authentic socialist practice. ${ }^{36}$

Amongst MacIntyre's interlocutors on the revolutionary wing of the New Left, Cliff Slaughter criticised him for his inadequate conceptualisation of conscious 'political leadership'. Against MacIntyre's suggestion that the party would merely mediate against the pressures of conformism inherent in bourgeois life, Slaughter insisted that it must be more than this: 'it must be the vanguard of revolutionary action' who would pass socialist theory 'from bourgeois intellectuals' to the working class 'from outside'. ${ }^{37}$

Slaughter's criticism of MacIntyre was tangential to the main focus of his essay which was intended as a critique of the ideas of Cornelius Castoriadis's journal Socialisme ou Barbarie. Castoriadis characterised capitalism through the idea of a 'permanent crisis' which 'owes its origin to the conflict at the point of production'. ${ }^{38}$ Prefiguring arguments outlined by MacIntyre in 'Freedom and Revolution', Castoriadis suggested that the 'proletariat's struggle against capitalism ... begins at the point of production' where there exists 'an autonomous development of the proletariat towards socialism'. Castoriadis believed that the

\footnotetext{
${ }^{34}$ Alasdair MacIntyre [1960] 2008, 'Breaking the Chains of Reason,' in Paul Blackledge \& Neil Davidson eds., Alasdair MacIntyre’s Engagement with Marxism: Essays and Articles 1953-1974, Leiden: Brill, p. 163.

${ }^{35}$ Alasdair MacIntyre, 'Breaking the Chains of Reason,' p. 165.

${ }^{36}$ Alasdair MacIntyre [1960] 2008, 'Freedom and Revolution’ in Paul Blackledge \& Neil Davidson eds., Alasdair MacIntyre's Engagement with Marxism: Essays and Articles 1953-1974, Leiden: Brill, p. 132

${ }^{37}$ Cliff Slaughter 1960, 'What is Revolutionary Leadership?' Labour Review Vol. 5, No. 3, Oct./Nov, pp. 107; 109.

${ }^{38}$ Cornelius Castoriadis [1959] 1988, 'Proletariat and Organisation I' in Cornelius Castoriadis Political and Social Writings Vol. II (Minneapolis: University of Minnesota Press), p. 195. This essay was first published in Socialisme ou Barbarie in 1959 and prefigures some themes found in MacIntyre's 'Freedom and Revolution'.
} 
role of socialists was, contra Lenin and Kautsky, not to bring consciousness to the working class from without, but to express and give shape to the struggle from below. ${ }^{39}$

As we have noted, it was to this model of socialist leadership that MacIntyre was drawn at the turn of the 1960s. And as against Slaughter's elitism, he repeatedly quoted the third of Marx's theses on Feuerbach: 'The materialist doctrine that men are products of circumstances and upbringing, and that, therefore, changed men are products of other circumstances and changed upbringing forgets that it is men that change circumstances and that the educator must himself be educated. Hence this doctrine necessarily arrives at dividing society into two parts, of which one is superior to society'. Commenting on these lines, MacIntyre wrote that 'As Marx saw it, this doctrine implies the sharpest of divisions in society between those who know and those who do not, the manipulators and the manipulated. Classical Marxism stands in stark contrast to this: it wants to transform the vast mass of mankind from victims and puppets into agents who are masters of their own lives. But Stalinism treated Marxist theory as the discovery of the objective and unchangeable laws of history, and glorified the party bureaucrats as the men who possessed the knowledge which enabled and entitled them to manipulate the rest of mankind'. ${ }^{40}$

Despite his affinities to Socialisme ou Barbarie, in 1960 MacIntyre joined the editorial board of the journal International Socialism. Associated with the ideas of Tony Cliff and Mike Kidron, International Socialism stood alongside Socialisme ou Barbarie in attempting to rethink the problem of socialist leadership through the lens of Marx's concept of proletarian self-emancipation. However, whereas Castoriadis made a fairly absolute break with Lenin, Cliff's criticisms were much more measured. ${ }^{41}$ This was true even in 1959 when he published a short study of Rosa Luxemburg's Marxism in which he argued that 'for Marxists, in advanced industrial countries, Lenin's original position can serve much less as a guide than Rosa Luxemburg's, notwithstanding her overstatements on the question of spontaneity'. ${ }^{42}$ A year later, he extended this argument to position himself some way between Castoriadis's spontaneism and Slaughter's elitism in which he argued that 'the revolutionary party must conduct a dialogue with the workers outside it. The party, in consequence, should not invent tactics out of thin air, but put as its first duty to learn from the experience of the mass movement and then generalise from it'. ${ }^{43}$ Against a top-down model of socialist leadership, Cliff insisted that 'the revolutionary party, while conscious of its leading role, must beware of slipping into a way of thinking that the party is the fount of all correct thoughts and deeds, while the working class remains an inert mass without initiative'. ${ }^{44}$ At this juncture Cliff's arguments were very close to those of MacIntyre, who in the pamphlet 'What is Marxist Theory For?', suggested that 'the only intellectual who can hope to aid the working class by theoretical work is the one who is willing to live in the working-class movement and learn from it, revising his concepts all the time in light of his and its experience'. ${ }^{45}$

\footnotetext{
${ }^{39}$ Cornelius Castoriadis 1988, 'Proletariat and Organisation I’, pp. 195; 199; 211

40 Alasdair MacIntyre 1960, ‘Communism and British Intellectuals’ in Paul Blackledge \& Neil Davidson eds., Alasdair MacIntyre’s Engagement with Marxism: Essays and Articles 1953-1974, Leiden: Brill, p. 119; cf Alasdair MacIntyre, 'Breaking the Chains of Reason' .

${ }^{41}$ See Ian Birchall 2011, Tony Cliff: A Marxist for his Time (London: Bookmarks), p.182

42 Tony Cliff [1959] 2002, 'Rosa Luxemburg' in Tony Cliff In the Thick of the Workers' Struggle (London: Bookmarks), p. 113.

${ }^{43}$ Tony Cliff [1960] 2002, 'Trotsky on Substitutionism' in Tony Cliff In the Thick of the Workers' Struggle, p. 122; 129. This essay was originally published as 'The Revolutionary Party and the Class, or Trotsky on Substitutionism' International Socialism 2, 1960.

${ }^{44}$ Tony Cliff, 'Rosa Luxemburg', p. 77.

45 Alasdair MacIntyre [1960] 2008, 'What is Marxist Theory For?’ in Paul Blackledge \& Neil Davidson eds., Alasdair MacIntyre's Engagement with Marxism: Essays and Articles 1953-1974, Leiden: Brill, p.100
} 
Over the next few years MacIntyre attempted to flesh out this conception of socialist leadership. In a response to 'The Case for Left Reformism' penned by Oxford labour historian Henry Collins, ${ }^{46}$ he argued that reformism was less a coherent response to the problems that beset the working class than it was a reflection of a particular moment in the history of capitalism. It arose 'within a capitalism which has learnt some degree of rationalisation and control'. ${ }^{47}$ Against Collins' claim that revolution was predicated, primarily, upon the impoverishment of the working class, MacIntyre suggested that socialism emerged as the experience of capitalism forced workers, first, to recognise their own unfreedom, and, second, to 'combine with other workers' to set themselves free. MacIntyre argued that the role of revolutionaries was to develop programmes that brought 'together three elements in our social life': 'the deep and incurable dissatisfaction with social life which capitalism breeds'; 'the recurrent state of objective crisis in capitalist social order'; and 'socialist theory'. 48

But how would this model work in periods when workers believed that they had, in the famous words of Harold Macmillan, 'never had it so good' in part because they were living through an economic boom that appeared to falsify Marx's claim that capitalism was an essentially contradictory and thus crisis prone system? By 1963 MacIntyre came to believe that contemporary economic trends had created barriers to the diffusion of socialist class consciousness across the working class. Specifically, post-war capitalism had been transformed by the 'conscious, intelligent innovation' of the bourgeoisie and its representatives. ${ }^{49}$ Furthermore, the working class had become increasingly fragmented: 'there is a sad case for saying that being in an economically strong position today against the employers in certain industries at least, means that the issues on which you are likely to fight and even possibly win are just the issues that are going to divide you from less skilled workers' ${ }^{50}$ A few years later he reinforced this claim through the suggestion that the attitudes of the British working class had been fixed within a reformist world-view since the nineteenth century: "They were not concerned with advancing the claims of one way of life against another; they were concerned with making claims for so much an hour". ${ }^{5}$

Prefiguring, as it does, the arguments of 'The Theses on Feuerbach: A Road Not Taken', this analysis appeared to imply damning consequences for the Marxist political project. Nevertheless, MacIntyre concluded 'Prediction and Politics' with a call to arms. Paralleling arguments first outlined on the pages of Socialisme ou Barbarie, MacIntyre argued that the condition for the fall of capitalism was the growth in socialist class consciousness within the proletariat, and, as this growth was neither inevitable nor impossible, it 'depends upon us' to make that change in consciousness. ${ }^{52}$

This voluntaristic conclusion represents a frankly astonishing volte face for MacIntyre. The arguments he had articulated in 1959-1960 clearly resonated with Marx’s

\footnotetext{
${ }^{46}$ Henry Collins 1961, 'The Case for Left Reformism’ International Socialism 6.

${ }^{47}$ Alasdair MacIntyre [1961] 2008, 'Rejoinder to Left Reformism’ in Paul Blackledge \& Neil Davidson eds., Alasdair MacIntyre’s Engagement with Marxism: Essays and Articles 1953-1974, Leiden: Brill, p.190.

${ }^{48}$ Alasdair MacIntyre, 'Rejoinder to Left Reformism', p. 196. Cornelius Castoriadis 1988, 'Modern Capitalism and revolution’ in Cornelius Castoriadis Political and Social Writings Vol. II

49 Alasdair MacIntyre [1963] 2008, 'Prediction and Politics' in Paul Blackledge \& Neil Davidson eds., Alasdair MacIntyre’s Engagement with Marxism: Essays and Articles 1953-1974, Leiden: Brill, p.256

${ }^{50}$ Alasdair MacIntyre 1963, Unpublished paper given to International Socialism day school, in Paul Blackledge \& Neil Davidson eds., Alasdair MacIntyre’s Engagement with Marxism: Essays and Articles 1953-1974, Leiden: Brill, p.226; cf Alasdair MacIntyre [1967] 2008, 'Herbert Marcuse’ in Paul Blackledge \& Neil Davidson eds., Alasdair MacIntyre’s Engagement with Marxism: Essays and Articles 1953-1974, Leiden: Brill.

${ }^{51}$ Alasdair MacIntyre 1967, Secularization and Moral Change (Oxford University Press), p. 27

${ }^{52}$ Alasdair MacIntyre, 'Prediction and Politics', p. 261. On Socialisme ou Barbarie's voluntarism see Alex Callinicos 1989, Trotskyism (London: Open University Press), p. 68
} 
claim that 'Communism is for us not a state of affairs which is to be established, an ideal to which reality [will] have to adjust itself. We call communism the real movement which abolishes the present state of things. The conditions of this movement result from the premises now in existence'. ${ }^{53}$ In 1963, by contrast, his perspective resembled nothing so much as the type of moralistic call to arms that Marx, following Fourier, had dismissed as 'impotence in action' ${ }^{54}$

It was against the voluntarism of this conclusion that Tony Cliff insisted that International Socialism republish Hal Draper's convoluted essay, 'The 'Inevitability of Socialism"' (1947), within which Draper attempted to square the demands of political activism with a highly deterministic interpretation of Marxism. ${ }^{55}$ Accordingly, Draper's essay was editorially introduced with the comment that it was being published 'as part supplement and part reply to Alasdair MacIntyre's 'Prediction and Politics'”.

Interestingly, MacIntyre’s next two contributions to International Socialism seemed, eclectically, to combine voluntarist and fatalist elements. First, in a paper presented to an International Socialism day-school in 1963, he followed Trotsky in suggesting that revolutionary leadership involved formulating a series of transitional demands which, while nominally reformist, could, in practice, only be realised through a revolutionary transformation of society. Second, in his last major article for International Socialism, he argued that revolutions emerge not from proletarian immiserisation, but rather out of 'period[s] of rising expectations'. Revolutions occur when 'the established order cannot satisfy the expectations which it has been forced to bring into being. The new capitalism cannot avoid calling into being a new working-class with large horizons'. Not that he believed such revolutions would automatically lead to the socialist transformation of society. As he had done in Prediction and Politics he again argued that there was nothing inevitable about the proletariat's ability to realise the potential generated by the new situation: 'whether on this contradiction it will or will not founder depends in part on the forms of our present activity'. ${ }^{56}$

One problem with this scenario is that the transitional demands, through which he hoped socialists might bridge the gap between the struggles in and against capitalism were an inadequate response to the challenges posed by a form of capitalism which, he believed, had escaped the boom-slump cycle. Indeed, whereas Trotsky had formulated the 'Transitional Programme' in conditions of deep economic crisis, it was not at all clear how similar demand in the context of massive economic growth would generate a revolutionary consciousness within the working class. ${ }^{57}$

It was in belated recognition of the hopelessness of this situation that MacIntyre eventually broke with Marxism in the mid to late 1960s. Interestingly, if Marxism: An Interpretation (1953) marked the moment of his own turn to politics, the second edition of that book, Marxism and Christianity (1968), marked his despair at the prospects for that project. Indeed, this is where he first condemned Marxism tout court rather than Stalinism specifically for its failure to sublate the limitations of liberalism or of what Marx would have called the standpoint of civil society. For though Marxism had promised to transcend the materialist and idealist modes of thought characteristic of bourgeois society, in practice

\footnotetext{
${ }^{53}$ Marx and Engels, 1976, The German Ideology, Collected Works Vol. 5, p. 49

${ }^{54}$ Marx, Karl 1975, 'The Holy Family', Collected Works Vol. 4, p. 201

${ }^{55}$ Hal Draper 1963, ‘The 'Inevitability of Socialism’’ International Socialism 15. This article was first published in New International in 1947.

${ }^{56}$ Alasdair MacIntyre [1963] 2008, 'Labour Policy and Capitalist Planning’ in Paul Blackledge \& Neil Davidson eds., Alasdair MacIntyre’s Engagement with Marxism: Essays and Articles 1953-1974, Leiden: Brill, p. 289

57 See John Molyneux 1981, Leon Trotsky's Theory of Revolution (London: Harvester), p. 182.
} 
because the revolutionary practice through which this sublation was to be realised failed to materialise, Marxists tended to revert back to one or other pre-Marxist mode of thought. ${ }^{58}$

Thus in Marxism and Christianity he argued that Marx's mature writings were guilty of a crime he sought to critique in others: the model presented in Capital acted as a barrier to understanding the modern world because it reified capitalism as an imminently 'selfdestructive' system in which the wills of proletarians and entrepreneurs are 'fixed and unalterable' such that individual capitalists were unable to do what they had in fact managed to do in the post-war period - 'become conscious of those workings in a way that enables him to modify them'. ${ }^{59}$ Moreover, this new development undermined Marx's revolutionary politics. Because Marx's political predictions were predicated upon, first, a model of deepening economic crisis coupled with, second, the growth in self-consciousness of the working class, once capitalists became conscious of the system and reshaped it accordingly then revolution would cease to be on the agenda. In this situation, an unbridgeable gulf opened between the reformist coordinates of contemporary politics and the revolutionary rhetoric of Marxists.

MacIntyre concluded that Marxism offered two inadequate answers to this question; those proffered by Kautsky and Lukács. As I noted above, he claimed that the former was effectively drawn to deify history in his attempt to theorise human agency. This is true enough, but because Marxism tends to be reduced to a version of Kautskyism only in secondrate textbooks, few actual Marxists would be troubled by the limitations of his interpretation of Marx's ideas. Indeed, even in his lifetime Kautsky's fall was dramatic. From being the 'Pope of Marxism' prior to the First World War, by the 1920s he was an isolated individual. Because he had tried to stem the growing polarisation between left and right within social democracy up to and after the War, once this polarisation matured into a split Kautsky's influenced quickly waned. ${ }^{60}$

Lukács is an altogether more contentious target. His History and Class Consciousness is without doubt the most important work of twentieth-century Marxist philosophy. Indeed MacIntyre acknowledges that this book is not merely 'a brilliant interpretation of Marx' but more importantly it 'made of Marxism what the Marxism of the Second International [pre-eminently Kautsky's Marxism - PB] was not, something to be reckoned with philosophically, even by those who rejected its claims' ${ }^{61}$ According to MacIntyre, Lukács argued that Marxism was the self-consciousness of capitalism as realised through the proletariat. However, there was a process of mediation in this argument such that class consciousness is actually embodied through the Communist Party. And while MacIntyre recognises the nuances in Lukács position - his model of the Communist Party was open and democratic and embodied through actual proletarians - he is also aware that because Lukács believed that the actually existing Communist Parties of the Third International under Stalin were such parties, when he was denounced by the Third International as a heretic he accepted the leadership's criticisms of his view and succumbed to party discipline. ${ }^{62}$ Thus despite the power of Lukács actual arguments, in practice he did come to substitute the Communist Parties for the working class in his model of Marxism. On this basis MacIntyre concludes his survey of contemporary Marxism with the claim that the gap between the actual movement of the working class and the revolutionary aspirations ascribed to it by Marxists can only be

\footnotetext{
${ }^{58}$ Alasdair MacIntyre, Marxism and Christianity, pp. 128; 99-101.

${ }^{59}$ Alasdair MacIntyre, Marxism and Christianity, pp. 81-84

${ }^{60}$ Paul Blackledge 2006, 'Karl Kautsky and Marxist Historiography’, Science and Society Vol. 70 No. 3: $337-$ 359

${ }^{61}$ Alasdair MacIntyre 2006, Edith Stein: A Philosophical Prologue (London: Continuum), pp. 171-172

${ }^{62}$ Alasdair MacIntyre, Marxism and Christianity, pp. 97-100
} 
solved theologically either through Lukács's 'deification of the Party,' or Kautsky's 'deification of history'. 63

This is all very plausible but for one problem: to fully substantiate his claim MacIntyre needs to show not that Lukács capitulated to Stalinism, but that this act was more than a contingent fact of his biography. But, to take a related example suggested by MacIntyre, the exemplary virtues exhibited by Trotsky surely include his refusal to capitulate to Stalinism. ${ }^{64}$ This was a commendable act in part because the pressures to capitulate were so very great, and these pressures were certainly strong enough in and of themselves to explain Lukács behaviour in the 1920s and 1930s. ${ }^{65}$ Of course, some have explained Lukács behaviour in terms of his understanding supposed reification of the Communist Party. But MacIntyre signals problems with this approach even if he doesn't explore it.

He didn't explore this issue, in part, because Lukács's argument was predicted upon Marx's claim that capitalism was a crisis prone system, and MacIntyre had come to believe that this model was no longer operative. Given this assumption, Lukács position is at best utopian. MacIntyre's dismissal of Lukács is nevertheless unfortunate both because the subsequent history of capitalism has tended to confirm Marx's account of its crisis prone essence $^{66}$ and, more positively, because Lukács did point towards a means of overcoming weaknesses with MacIntyre's earlier conception of socialist political activity. Whereas Cliff Slaughter had rehearsed an elitist form of revolutionary politics which certainly did tend to deify 'the party', the position MacIntyre outlined in 1959-60 had the strength of being rooted in the real movement from below. Unfortunately, MacIntyre was so keen to distance himself from the dualistic conception of leadership expressed by Lenin's epigones that he erred in the opposite direction. So in contrast to Slaughter's sectarian perspective, MacIntyre's approach tended to justify liquidating the socialist party into the working-class movement. And because his model of leadership tended merely to reflect the movement from below, it was susceptible to crisis if and when this movement ebbed. This weakness was of course the flipside of its strength - it would tend to rise and fall with the ebb and flow of the real movement.

In a sense, MacIntyre's conception of revolutionary leadership can be understood as paralleling weaknesses with Edward Thompson's notion of class. In a brilliant counter to the reified abstractions of Stalinist historiography Thompson, in his groundbreaking classic The Making of the English Working Class, attempted to reinsert human agency into historical materialism. However, despite the undoubted strengths of his approach, because he tended to reduce class to class consciousness his method obscured the salience of class in periods when class consciousness was at a minimum. ${ }^{67}$ Similarly, MacIntyre's conception of socialist politics was weakened by its seeming embrace of an inadequately mediated relationship to the 'real movement of things'. When the movement was on the up, MacIntyre's approach could easily express its confidence. Conversely, his own pessimism grew as a direct consequence of the decline of the movement. And this pessimism was reinforced by the way he conceived the economic boom as a consequence of deliberate (Keynesian) policies. In a sense MacIntyre's approach was too Hegelian: his focus on the idea of proletarian selfemancipation informed a weak conception of the mediated relationship between the socialist

\footnotetext{
${ }^{63}$ Alasdair MacIntyre, Marxism and Christianity, p. 101

${ }^{64}$ Alasdair MacIntyre, After Virtue, p. 199

65 On Lukács’s Marxism and his capitulation to Stalinism see John Rees 2000, ‘Introduction’ in Georg Lukács, Tailism and the Dialectic: A Defence of History and Class Consciousness (London: Verso)

${ }^{66}$ Chris Harman 2009, Zombie Capitalism (Chicago: Haymarket)

${ }^{67}$ E. P. Thompson 1980, The Making of the English Working Class (London: Penguin), pp. 8-13; compare Thompson's approach with Geoffrey de Ste. Croix 1983, The Class Struggle in the Ancient Greek World (London: Duckworth).
} 
party and the 'real movement of things.' This meant he did not have the theoretical resources necessary to stand against the temporary shift to the right that occurred in the mid 1960s. Indeed, he effectively reified the non-revolutionary context in which he operated. Unfortunately, though other theorists associated with International Socialism did have the theoretical resources necessary to make sense of the transient character of this context, ${ }^{68}$ MacIntyre remained unconvinced by their arguments in part because they were hitched onto Draper's unsuccessful defence of the inevitability of socialism.

By contrast with MacIntyre's conception of socialist leadership, it is a great strength of Lukács's position that he recognised that 'the class consciousness of the proletariat does not develop uniformly throughout the whole proletariat'. Consequently, a communist party could 'only be created through struggle' and in particular through the 'interaction of spontaneity and conscious control'. ${ }^{69}$ So while Lukács distanced his ideas from those sectarians who deified the party as 'the representative of the 'unconscious' masses', he did so without flipping over into the opposite error of embracing a simplistic deification of spontaneity. ${ }^{70}$ Thus his use of the most contentious term in History and Class Consciousness: 'imputed consciousness'. ${ }^{71}$ While often presented as the means through which he did deify the party, this term is best understood as the corollary of Marx's essentialist model of social class. ${ }^{72}$ Far from allowing Lukács to slip back towards a form of dualism, it opened a space within which he was able to conceptualise socialist political intervention within the class struggle in a non-emotivist but yet activist way by means of the generalisations about class interests that could be made on the basis of the history of workers' struggles. For instance, to say that workers have an objective interest in challenging racism even in the absence of an anti-racist movement does not imply imposing the idea of anti-racism onto the working class. Rather, it functions as a generalisation about objective interests made on the basis of previous moments of struggle. This way of thinking about politics opens the door to an interventionist conception of political leadership that escapes the emotivist substitutionism of self-appointed vanguards without liquidating the left into a (retreating) movement. ${ }^{73}$

\section{Conclusion}

In 1960, Edward Thompson argued that MacIntyre's stress on politics at the point of production was the $\mathrm{ABC}$ of Marxism with the $\mathrm{B}$ and $\mathrm{C}$ left out. ${ }^{74}$ With this argument, Thompson highlighted a central flaw in MacIntyre's politics. In the 1960s, MacIntyre's conceptualisation of the role of revolutionary leadership was innocent of either a concrete analysis of the complex nature of the class struggle suggested by Thompson, or of a concrete model of the role of revolutionaries within that struggle. Unfortunately, to the extent that a coherent approach to politics was formulated within International Socialism, it was philosophically underpinned by Hal Draper's untenable defence of the inevitability of socialism. While MacIntyre was justified in rejecting the kind of inevitabilism Draper shared with Kautsky, his rejection of Lukács' much more sophisticated defence of revolutionary socialism is less convincing. This is important because the pessimistic political conclusions to which he evolved in the 1960s were deeply informed by his weak model of the role and

\footnotetext{
${ }^{68}$ Mike Kidron 1961, 'Reform and Revolution’ International Socialism 7, p. 15

${ }^{69}$ Georg Lukács 1971, History and Class Consciousness (London: Merlin), pp. 304; 317

${ }^{70}$ Georg Lukács, History and Class Consciousness, p. 322

${ }^{71}$ Georg Lukács, History and Class Consciousness, p. 323

${ }^{72}$ Georg Lukács, History and Class Consciousness, p. 325

73 Alex Callinicos 2007, 'Leninism in the Twenty-First Century?' in Sebastian Budgen et al eds Lenin Reloaded

Duke University Press, p. 26; Alex Callinicos 2006, Resources of Critique, Cambridge: Polity, p. 119

${ }^{74}$ Edward Thompson 1960, 'The Point of Production' New Left Review 1, pp. 68-70
} 
nature of political leadership in the emergence of proletarian socialist class consciousness. In the late 1950s and early 1960s, the limitations of MacIntyre's conceptualisation of socialist leadership were masked by the upturn in the political struggle that gave rise to the first New Left and Campaign for Nuclear Disarmament. However, with the defeat of these movements in the early 1960s, the inadequacies of his increasingly voluntarist model of socialist politics were brought into sharp relief by his inability to provide a socialist explanation for the limits of mass proletarian apathy.

When, in the 1970s, Marxists again debated the issue of morality, MacIntyre's contribution to this debate was largely overlooked, in part because of his subsequent political evolution. ${ }^{75}$ This is unfortunate, for MacIntyre's break with the revolutionary left was informed by the very seriousness with which he understood Marxism. He could no more embrace utopian Marxism, à la G.A. Cohen, ${ }^{76}$ than he could Kantianism; his Aristotelianism provided a political way out of his interpretation of the impasse of socialist politics. If we are to maintain a commitment to revolutionary politics while avoiding MacIntyre's pessimism, it is incumbent upon us to formulate a better model of the relationship between struggles in and against capitalism and the role of socialists within them. So, while MacIntyre's recent rethink of the concepts of desire and human nature, and the labour theory of value have created a space through which Marxists might reengage with his ideas, to realise its potential such a dialogue must re-engage with the limitations as well as the strengths of MacIntyre's critique of Lenin and Lukács.

\footnotetext{
${ }^{75}$ See, for instance, Perry Anderson 1980, Arguments Within English Marxism (London: Verso), p. 108.

${ }^{76}$ G.A. Cohen 2000, If You're an Egalitarian, How Come You're So Rich? (Harvard University Press)
} 